\title{
The Guild of Our Lady of Ransom and Pilgrimage in England and Wales, c. 1890-1914
}

\author{
Kathryn Hurlock \\ Department of History, Politics and Philosophy, Manchester Metropolitan \\ University, 4 Rosamund Street West, Oxford Road, Manchester, M15 6LL, UK. \\ Email: K.Hurlock@mmu.ac.uk
}

\begin{abstract}
The growth in Catholic pilgrimage in the late nineteenth and early twentieth century is widely acknowledged, but little attention has been paid to how and why many of the mass pilgrimages of the era began. This article will assess the contribution made by the Guild of Our Lady of Ransom to the growth of Catholic pilgrimage. After the Guild's foundation in 1887, its leadership revived or restored pilgrimages to pre- and post-Reformation sites, and coordinated the movement of thousands of pilgrims across the country. This article offers an examination of how and why Guild leaders chose particular locations in the context of Marian Revivalism, papal interest in the English martyrs, defence of the Catholic faith, and late-nineteenth century medievalism. It argues that the Guild was pivotal in establishing some of England's most famous postReformation pilgrimages. In doing so, it situates the work of the Guild in late nineteenth and early twentieth century religiosity, and demonstrates the pivotal nature of its work in establishing, developing, organising, and promoting some of the most important post-Reformation Catholic pilgrimages in Britain.
\end{abstract}

Keywords: Pilgrimage, Guilds, English Martyrs, Marian Shrines

I $\mathrm{n}$ the decades after the emancipation of Catholics in England and Wales $(1829)^{1}$, and the restoration of the Catholic hierarchy (1850), pilgrimage activity increased within Britain, as well as to sites overseas. By the 1880 s, there had been a clear rise in large-scale organised pilgrimages, such as that to Paray-le-Monial in southern Burgandy, France in 1873, to Canterbury in 1883, and Lindisfarne in 1887. These were partially inspired by the 'National Pilgrimages' in France in the 1870 s, themselves stimulated by a resurgence of Catholic piety following the Paris Commune of 1871, a belief that France needed to conduct pilgrimages of expiation for its collective sins, and the desire for a response to republican anti-clericalism. ${ }^{2}$

\footnotetext{
${ }^{1}$ An Act for the Relief of His Majesty's Roman Catholic Subjects, 1829, 10 Geo.4 c.7.

${ }^{2}$ Katherine Haldane Grenier, "Public acts of faith and devotion": pilgrimages in late $19^{\text {th }}$ century England and Scotland', in Alisa Clapp-Intyre and Julie Meinyk, eds. "Perplext in faith": essays on Victorian beliefs (Newcastle-Upon-Tyne: Cambridge Scholars Publishing,
} 
In some respects, the mass pilgrimages in England and Wales, and those of 1870s France, were a means by which the Catholic community could express its faith in the face of widespread - and sometimes hostile - opposition. In the final decades of the nineteenth century, these large and well-organised pilgrimages became an increasingly common sight in England and Wales and, in some cases, were established as annual events at several sites across the country. In their discussion of the tradition of pilgrimage to Walsingham, Simon Coleman and John Elsner observe that pilgrims who make the journey year after year construct 'personal traditions ... that make each subsequent visit richer in its personal and 'life-historical' associations'. ${ }^{3}$ The Guild of Our Lady of Ransom, founded in the late 1880s with the express purpose of interceding for the conversion of England and Wales, was pivotal to the institution of a tradition of annual pilgrimages.

This article examines the role played by the Guild of Our Lady of Ransom in the revival and restoration of pilgrimage. Although the role of the Guild in this renaissance has been acknowledged, albeit briefly, there has been no detailed study of the Guild's pilgrimage activity. Analysis of its role in both the revival of medieval pilgrimage sites and the establishment of new ones has not been undertaken. ${ }^{4} \mathrm{An}$ investigation into how and why specific pilgrimage locations were chosen by the Guild will shed light on the development of its spiritual practices in the late nineteenth and early twentieth centuries, and on the significance of its contribution to the revival and renewal of British Catholic pilgrimage. Equally, it develops our understanding of latenineteenth century responses to pilgrimage, the importance of pre- and post-Reformation English martyrs to pilgrimage and identity, and the ways in which modern advertising, incentives, and travel methods were harnessed to attract significant numbers of pilgrims.

\section{Origins, aims and membership of the Guild}

The Guild of Our Lady of Ransom was founded in November 1887 by Fr Philip Fletcher (1848-1928), a former Anglican priest, and his fellow convert Lister Drummond (1856-1916). It was formed comparatively late, as most dioceses could already boast a society of some kind by the

2015), 149-63; Camille Barrere, 'Pilgrimages and Catholicism in France', Fraser's Magazine, 8 November 1873, 608-14; Brian Brennan, 'Visiting "Peter in Chains": French Pilgrimage to Rome, 1873-93', Journal of Ecclesiastical History 51 (2000): 741-66; Marc Agostino, 'The golden age of pilgrimages in France in the nineteenth century', in Antón M. Pazos, ed. Nineteenth century European pilgrimages (Abingdon: Ashgate, 2020), 121-37 at 127; Susanne F. Kaufmann, Consuming visions: mass culture and the Lourdes shrine (Ithaca: Cornell University Press, 2005), 25-56.

3 Simon Coleman and John Elsner, 'Tradition as Play: pilgrimage to "England's Nazareth", History and Anthropology 15 (2004): 273-88, at 284.

4 Dominic Aidan Bellenger, 'England's Nazareth: the revival of the Roman Catholic shrine at Walsingham, 1897-1997', The Downside Review (1998): 273-74; Grenier, 'Public acts', 159, 61. 
1860s. Fr Fletcher had begun his main work - to bring about the conversion of England and Wales - the previous year, and his chief method was through prayer conducted by members of his newly-founded confraternity, the Union of Intercession for the Conversion of England. ${ }^{5}$ The specific focus of the confraternity aligned with the aims of other societies established in the last decades of the century, which had a greater emphasis on devotion, in contrast to their earlier counterparts, which were established to meet the specific needs of churches. ${ }^{6}$

In 1887, Drummond convinced Fr Fletcher to develop the Union to promote the role of prayer alongside other works as a tool for conversion. Consequently, the Union was replaced by the Guild of Our Lady of Ransom, formally drawn up on St Willibrord's Day, 29 November 1887, with Fr Fletcher as leader and Drummond as secretary. ${ }^{7}$ The Guild's foundation came at the end of a decade of concern amongst Christian churches that Britain was increasingly secularised, and that the effort to convert people to faith was failing. ${ }^{8}$ Other existing organisations, such as the Crusade of St George, and the Confraternity of St Wilfrid for the Conversion of the Isle of Wight, had similar aims, but the Guild became by far the largest. ${ }^{9}$ It had many ways of encouraging conversions: processions, public preaching, Fr Fletcher's regular publications in the Catholic press, and a series of tracts on the Catholic religion. However, there was a recognition that pilgrimage was the most effective way of spreading their message and of achieving their aims. ${ }^{10}$ Ransomers, as members of the Guild were sometimes known, were initially interested in overseas pilgrimage, but soon settled on British pilgrimages and developed the nine (Canterbury, Chelsea, Hastings, Padley, St Winefride's Well, King's Lynn and Walsingham, Westminster, Willesden, York) pilgrimages discussed here. ${ }^{11}$ Fr Fletcher was only able to pour his energy into these large-scale events once he had given up his parochial duties in 1891, something he claimed he did at the urging of the Dowager Duchess of Norfolk, and with the permission of his superior, Bishop Butt of Southwark $(1826-1899) .{ }^{12}$

\footnotetext{
${ }^{5}$ Henry Charles Kent, 'A People's Ransom', Catholic World 334-336 (1893): 693.

${ }^{6}$ Mary Heimann, Catholic Devotion in Victorian England (Oxford: Clarendon, 1995), 125-27.

7 'Obituary: Mr Lister Drummond, KSG', Tablet, 4 March 1916, 319; Philip Fletcher, Recollections of a Ransomer (London: Sands \& Co., 1928), 54.

${ }^{8}$ Mary Heimann, "Christian piety in Britain during the "long" nineteenth century, c. 1780-1920', in Anders Jarlet, ed. Piety and modernity: the dynamics of religious reform in northern Europe, 1780-1920 (Leuven: Leuven University Press, 2012), 27-54 at 49.

9 'Conversion of England [Letter]', Tablet, 15 September 1888, 418.

10 'Obituary: The Rev P. Fletcher, K.C.H.S', Tablet, 21 January 1928, 80; 'Gratuitous distribution of Catholic literature', Tablet, 14 September 1895, 419.

11 'The Ransom pilgrimage to Lourdes', Tablet, 24 September 1892, 500-1; 'English pilgrimage to Boulogne', Tablet, 19 August 1891, 341; The Sacred Heart Review 12, 11 August 1894, 16.

${ }^{12}$ Fletcher, Recollections, 57, 149.
} 
The Guild aimed to free spiritual captives and aid their return to the true faith. It took as its model two medieval orders aimed at the redemption of physical captives: the Trinitarians, established in the late twelfth century, and the mendicant Order of Our Lady of Mercy for the Redemption of Captives (Mercedarians), established in the thirteenth century. ${ }^{13}$ The Mercedarians celebrated the Feast of Our Lady of Ransom on the anniversary of their foundation. Significantly, however, the Guild, whilst inspired by medieval orders, took as its prayer that of the Venerable Henry Heath on the scaffold at Tyburn in 1643: 'Jesu convert England, have mercy on this country'. Moreover, the Guild was dedicated to the Blessed Lady, St Gregory, and the English Martyrs, chosen because Fr Fletcher was 'mindful of the national as well as the Catholic character of his work. ${ }^{14}$ Reference to both the medieval and early modern heritage on which the Guild drew gave it authority and established it in the traditions of the wider Catholic Church.

The Ransomers were organised into local branches; members were signed up at religious services or through the efforts of branch leaders. Branches were widespread, and could be found in major cities such as Liverpool, Cardiff, and Sheffield, as well as smaller towns such as Hastings, Morpeth, Totnes, Ruthin, and Luton, making the Guild more national in scope than many Catholic societies. ${ }^{15}$ Members were divided into White Cross Ransomers (priests), Red Cross Ransomers (charged with praying and working for conversion, and from whom branch leadership was drawn), and Blue Cross Ransomers (who were expected to pray daily for the conversion of England). ${ }^{16}$ The Guild grew rapidly: there were 10,000 members after two years, and 100,000 by 1902 , by which time it was believed to be the 'most popular and largest' of any of the Catholic confraternities. ${ }^{17}$

The timing of the Guild's foundation was highly significant. In a brief history of the Guild written in 1893, Henry Charles Kent commented: 'Twenty years ago, such an organisation would have been impracticable, and if started would have had little prospect of bearing fruit. To-day it is not only possible, but has been accepted without

13 James William Brodman, Ransom captives in Crusader Spain: the Order of Merced on the Christian-Islamic frontier (Philadelphia: University of Pennsylvania Press, 1986); John Flannery, 'The Trinitarian Order and the ransom of Christian captives', Al-Masāq: Journal of the Medieval Mediterranean 23 (2011): 135-44.

14 Kent, 'A people's Ransom', 696. For the rationale for the Guild, see its current website: [http://www.guild-ransom.co.uk/about-us Accessed 29/06/2020].

${ }_{15}$ The monitor, Catholic organ for Great Britain, 25 February 1898, 3; 'Ransom reunion at Ruthin', Denbighshire Free Press, 20 June 1896, 8; Heimann, Catholic, 125-7.

16 Fletcher, Recollections, 54-6.

17 Henry Browne, The Catholic Evidence Movement: its achievements and hopes (London: Burns Oates \& Washbourne, 1921), 2; 'Guild of Our Lady of Ransom', Tablet, 28 September 1889, 514; The American Catholic Quarterly, 16 (1891): 372; London Daily News, 24 April 1902, 5. 
a murmur from the English community. ${ }^{18}$ As a Catholic writer, Kent downplayed opposition to some Guild activities, but he was right about timing: an increase in ultramontane spirituality, whose adherents were 'drawn to pilgrimages, rosaries, and extravagant devotions', fed into the rise and success of the Guild, and to the growing interest in public expressions of devotion..$^{19}$ By 1900, some Catholic pamphleteers felt confident enough to claim that Catholics were finally able to "breathe and walk without fear, and to speak freely. ${ }^{20}$ In reality, devotional change in the later nineteenth century was due to a range of influences: such a public-facing society was able to thrive in the 1890s, due, at least in part, to the increasing toleration of Catholicism since the Papal Aggression fears of 1850-51.

Guild members were predominantly middle or working class. For example, Mr G E George Anstruther ( $b .1870)$, the Guild's Recorder, was a clerk and sometime lecturer, whose wife ran the local Catholic Repository. In 1907, he perhaps idealistically wrote that class distinctions had no place in the Guild, as successful work in conversion was what mattered. ${ }^{21}$ The Yorkshire Gazette reporter noted that the 1892 York pilgrims 'appeared to consist entirely of the middle and working class' ${ }^{22}$ On the whole, there was very little interest in the Guild among the upper classes, whether converts or old Catholic families, though there were exceptions. Count Rivarola organised local transport for Ramsgate pilgrims to Canterbury in $1899,{ }^{23}$ while the elite of the Catholic Church, including Cardinal Henry Manning, archbishop of Westminster (18081892), and his successor Cardinal Herbert Vaughan, archbishop of Westminster (1832-1903) were members. ${ }^{24}$ For all concerned, however, the individual motivations of the pilgrims who took part are unknown, as the surviving evidence speaks only of the corporate aims of the Guild.

Most Catholics in England and Wales at this time were Irish and working-class, and several Irish ecclesiastics and abbots attended pilgrimages and delivered sermons for the Guild. However, importantly, there was no reference in the newspapers to their role. This may, in part, have been due to the nature of the reporting - the Tablet, for example, was controlled by the anti-Irish Cardinal Vaughan and so perhaps chose

18 Kent, 'People's Ransom', 692.

19 Mary Heimann, 'Devotional stereotypes in English Catholicism, 1850-1914', in Frank Tallett and Nicholas Atkin, eds. Catholicism in Britain and France since 1789 (Cambridge: Hambledon Press, 1996), 13-25 at 16.

20 Dermot Quinn, Patronage and Piety: the Politics of English Roman Catholicism, 1850-1900 (Stanford University Press, 1993), 176.

211901 England, Wales \& Scotland Census (St Pancras): RG13.154.12, 16; G. Elliot Anstruther,

'The "Ransomers": a Catholic forward movement', New Catholic World 86 (1907/8), 640.

22 'Pilgrimage to York', Yorkshire Gazette, 11 June 1892, 5.

23 'Guild of Our Lady of Ransom', Thant Advertiser 17 June 1899, 4.

${ }^{24}$ It is possible that the upper class reserved their interest for the overseas pilgrimages organised by the Guild. Arundel Castle Archives MS MD 1137; Kent, 'People's Ransom', 699. 
not to acknowledge the Irish presence amongst pilgrims. ${ }^{25} \mathrm{~A}$ large proportion of the pilgrims were, however, undoubtedly, Irish. The English Martyrs Church, Tower Hill, site of early processions, had been built for a mostly Irish population ${ }^{26}$ while the 28 churches from Liverpool which sent pilgrims to Holywell in 1895 were located in overwhelmingly poor Irish areas. The parish of St Francis Xavier in Liverpool, for example, served a parish of 'the low Irish from the bottom parts of the city' following railway clearances, while the parish of St Alexander's, Bootle, which headed the pilgrimage procession under their own Ransom banner, served the Irish population of the slums. ${ }^{27}$ Yet the only non-English or Welsh group who were openly acknowledged as having taken part in pilgrimages were Italian Catholics from London, primarily from the parish of St Peter's in Hatton Garden. Their participation coincided with the construction of their new parish church in Clerkenwell, at the time the largest Roman Catholic church in Britain. ${ }^{28}$

The Guild was particularly attractive to Catholic converts: in addition to its founders, the treasurer, several secretaries, many branch leaders, and the priest assistant to Fr Fletcher were converts. Many of the identifiable pilgrims and preachers were also converts. ${ }^{29}$ That converts were at the forefront of developing a guild centred on conversion is not surprising. Patrick Allitt has argued that converts were the Church's strongest advocates, 'impressed by their own example' and determined to show Protestants the errors of their faith. ${ }^{30}$ Membership of a Guild with conversion at its heart also no doubt helped mitigate the social isolation many converts felt when they abandoned their old faith. Conversion could mean social, political, and often financial hardship, as later typified in the novels of Evelyn Waugh. ${ }^{31}$

${ }^{25}$ Sheridan Gilley, 'The Years of Equipose, 1892-1943', in V. Alan McClelland and Michael Hodgetts, eds. From without the Flamian Gate: 150 years of Roman Catholicism in England and Wales, 1850-2000 (London: Darton, Longman and Todd, 1999), 21-61, at 24; Derek Holmes, More Roman than Rome: English Catholicism in the Nineteenth Century (London: Burns \& Oates, 1978), 200.

${ }^{26}$ Lucy Underwood, 'English Catholic martyrs', in Gareth Atkins, ed. Making and remaking saints in nineteenth-century Britain (Manchester: Manchester University Press, 2016), 144-50, at 156 .

27 John Belchem, Irish, Catholic, and Scouse: the history of the Liverpool Irish, 1800-1939 (Liverpool: Liverpool University Press, 2007), 64.

28 'A Sussex pilgrimage', The Aberystwyth Observer, 13 August 1903, 2; Denis Evison, Catholic Churches of London (Sheffield: Sheffield Academic Press, 1998), 78; Hastings and St Leonard's Observer, 7 August 1897, 7.

${ }^{29}$ Fletcher, Recollections, 56; 'Obituary', The Times, 22 October 1948, 7; 'Et Caetera', Tablet, 25 February 1928, 255; W. Gordon Gorman, Converts to Rome: a biographical list of the more notable converts to the Catholic Church in the United Kingdom (London: Sands \& Co., 1910), 90, 97, 105.

${ }^{30}$ Patrick Allitt, Catholic converts: British and American Intellectuals turn to Rome (Ithaca: Cornell University Press, 1997), 1.

31 Dermot Quinn, Patronage and Piety: the Politics of English Roman Catholicism, 1850-1900 (Stanford: Stanford University Press, 1993), 5; Evelyn Waugh ed. R. M. Davis (St Louis: Herder, 1969), 41; Catherine Daniel, 'Catholic Converts in Wales', The Furrow 7 (1956), 211-25. 
The Guild's work was blessed by Pope Leo XIII (1810-1903), who pronounced himself the Guild's 'president' in May 1899, a role adopted by subsequent popes. ${ }^{32}$ In 1901 Drummond was presented with the Insignia of the Order of St Gregory 'in recognition of his apostolic work', and in 1920 Fr Fletcher was made Knight Commander of the Holy Sepulchre. ${ }^{33}$ The Guild, and Fr Fletcher in particular, were encouraged by the Catholic hierarchy of England and Wales: the archbishop of Westminster said mass for the Guild and blessed its work, while the bishop of Liverpool was described as 'interested in and zealous' for the Guild. ${ }^{34}$ At the end of his autobiography, Fr Fletcher listed twenty archbishops and bishops in England who had supported his efforts, and thanked them 'for the encouragement they have always given me in the prayers and works for the conversion of England. ${ }^{35}$

Fr Fletcher kept no personal or Guild archive, but he was a prolific writer. The vast majority of information on the Guild is found in newspapers and journal articles he wrote, often for his own publications, as well as his autobiography. ${ }^{36} \mathrm{He}$ promoted the message of conversion in articles for The Catholic Register and The Catholic News. He ran a Guild newsletter, Faith of Our Fathers, and started a monthly publication, The Ransomer in 1893, which ran for several years before being absorbed by The Catholic Standard and then the Monitor. Later in life, he began a second publication, The Second Spring. He also occasionally had his letters published in the wider Catholic press. ${ }^{37}$ These publications may have provided an income, though he primarily funded himself and the Guild's work through payments from 'sermons, addresses, re-unions and pilgrimages', and funds sent in to the Guild's treasurer. He received an annual income for lodging from an unnamed source - perhaps the Dowager Duchess of Norfolk, whom he described as 'a mother to me' - but donated it to fund a student at a seminary. Instead, he relied on local presbyteries, monasteries, and seminaries for food and accommodation. ${ }^{38}$

\section{Pilgrimages in honour of the Virgin Mary and pre-Reformation saints}

The mass pilgrimages instituted by the Guild fell into two camps: the revival of old, pre-Reformation pilgrimages, often in honour of the

32 Kent, 'People's Ransom', 699.

33 'Obituary: the Rev P. Fletcher', 80; Fletcher, Recollections, 124.

34 'Letter', Tablet, 22 September 1888, 22; 'The "Ransomers" again', Sheffield Daily Telegraph, 30 November 1892, 6; Fletcher, Recollections, 151.

35 Fletcher, Recollections, 164.

36 For a discussion of the limited sources for the Guild, see Robin Gard, 'The Archives of Catholic Lay Societies', Catholic Archives 22 (2004), 26-29. The Guild does hold a small amount of archival material at its office in Wimbledon, but it has little for the period discussed in this article.

37 Robin Gard, 'The archives of the Catholic lay societies', Catholic Archives 22 (2002): 26-7; Fletcher, Recollections, 114-16.

38 Fletcher, Recollections, 57, 149; 'Letter from Lister Drummond', Tablet, 24 November 1888, 824; London Monitor, 25 November 1898, 3. 
Virgin Mary, and the establishment of new pilgrimages in honour of the post-Reformation Martyrs. Interest in Marian devotion had grown since the mid-nineteenth century, but pilgrimages to Marian sites were arguably stimulated by the rapid growth of Lourdes after 1858. In England and Wales, the figure of the Virgin Mary was used to create 'corporate identity' via confraternities and to express connection to Rome, one of the chief reasons her cult was so vehemently opposed by anti-Catholics. ${ }^{39}$ Pre-Reformation pilgrimage sites also served the purpose of rooting Catholicism in England, highlighting its historical traditions. This came at a time of growing interest in England's past, and a particular strain of nostalgia which looked back to pre-Industrial England as something of an ideal. ${ }^{40}$ Paul Readman argues that the past was used in this period to provide a 'key sense of national identity', and 'a localised sense of Englishness' ${ }^{41}$ Though he does not address the use of the past in a religious context, it is clear that the Guild used the past in a similar way, to provide a sense of continuity for the Catholic community. In this respect the Guild was actually similar to the Anglican Church around this time, which chose to reinvigorate interest in English saints like St Alban and incorporate them into religious discourse 'as a means for the propagation of Anglican identity. ${ }^{42}$ The Guild's choices may thus have been an answer to these developments.

In the decade following the foundation of the Guild, the first large historical pageants staged in England began, focusing on England's medieval past as a way of 'forming and sustaining identities' in the communities enacting and viewing them. ${ }^{43}$ It was important for Catholics to demonstrate continuity with the medieval, Catholic, English past as a way of affirming their group identity, and of legitimising their right to practice their religion in England. There was a sense that Catholics had been denied what was rightfully, historically, theirs. When the Rev. W. Croke Robinson preached the opening sermon of the 1893 York pilgrimage, he complained that Catholics had been 'cast out of their rights' and that when he visited York Minster, a medieval edifice built by and for Catholics, 'he was a foreigner, a visitor'. ${ }^{44}$ But the emphasis on their historic presence also came in response to external pressure, as it was criticism of Catholics as not really

39 John Singleton, 'The Virgin Mary and Religious Conflict in Victorian Britain', Journal of Ecclesiastical History 43 (1992), 16-34, at 21-23; Carol Engelhart Herringer, 'The Virgin Mary', in Atkins, ed. Making and Remaking Saints, 44-59, at 51.

${ }_{40}$ Paul Readman, 'The place of the past in English culture, c. 1890-1914', Past \& Present 46 (2005): $147-99$ at 147.

${ }^{41}$ Readman, 'The place of the past', 149.

42 Elizabeth MacFarlane, 'Pilgrimage and Cathedrals in the Victorian Era', in Dee Dyas and John Jenkins, eds. Pilgrimages and England's Cathedrals: Past, Present and Future (Cham: Springer International, 2020), $109-129$, at 110.

${ }_{43}$ A. Bartie et. al. 'Historical Pageants and the Medieval Past in Twentieth Century England', English Historical Review 133 (2018), 899.

44 York Herald, 9 June 1893, 6. 
English that led them to 'assert their deep patriotic roots' by harking back to the medieval past when England had been Catholic. ${ }^{45}$

Fr Fletcher later claimed that the Guild had 'gone in especially for restoring pilgrimage to the old English shrines' ${ }^{46}$ Their first pilgrimage, to Canterbury, took place on 7 July 1890, in celebration of the Feast of the Translation of St Thomas Becket. It was a significant and symbolic choice. By the mid-nineteenth century, understandings of Becket had shifted from that of 'ultramontane conspirator ... [to] activist sprung from the middle classes of London'; by the 1890s he was seen 'not only as a great Englishman, but a great patriot', with a wide appeal to Catholics and Anglicans. ${ }^{47}$ Drummond, organiser of the first Canterbury pilgrimage, was unsure if as many as 50 people would respond to his advertisement for train tickets from London, but in the end there was a turnout of several hundred pilgrims. ${ }^{48}$ Within a few years, the Canterbury pilgrimage was attracting over a thousand pilgrims, and by the end of the decade it had grown so much that it was considered by the local secular press as 'one of the grandest religious spectacles to be seen. ${ }^{49}$ Other medieval sites were also revived at this time. In 1890, the Guild undertook their first organised pilgrimage to the shrine of St Edward the Confessor in Westminster Abbey. ${ }^{50}$ Two years later, it reinstituted pilgrimages to York; and, at the turn of the century, it conducted its first pilgrimage to St Albans. ${ }^{51}$

The tolerance extended to these pilgrimages varied. Much depended on the custodians of the pilgrimage site, and their relationship with $\mathrm{Fr}$ Fletcher. The early response was very accommodating. In Westminster, pilgrims took turns with other visitors in accessing the Confessor's shrine, where they crossed themselves and then quietly knelt in prayer. ${ }^{52}$ At Llandaff, they 'knelt devoutly' while Father Cormack 'recited in a low tone prayers for the conversion to the Ancient Faith. ${ }^{53}$ There was some 'anxiety' about how the pilgrimage would be received in York, but pilgrims were treated 'courteously' by

\footnotetext{
45 John Wolffe, 'North-Atlantic anti-Catholicism in the nineteenth century: a comparative overview', in Y.M. Werner and J. Harvard, eds. European Anti-Catholicism in a Comparative and Transnational Context (Amsterdam: Rodopi, 2013), 25-42, at 37.

46 Fletcher, Recollections, 71.

47 Nicholas Vincent, 'Thomas Becket', in Atkins, ed. Making and Remaking Saints, 92-111, at $92,94-5,103$.

48 'Pilgrimage to Canterbury', Tablet, 21 June 1890, 983; 'The Pilgrimage to Canterbury', Tablet, 12 July 1890, 57; 'Pilgrimage to Canterbury', Tablet, 29 July 1893, 185; London Daily News, 24 April 1902, 5.

49 'Guild of Our Lady of Ransom', Thanet Advertiser, 17 June 1899, 4.

50 'Westminster', Tablet, 18 October 1890, 636; 'Notes', Tablet, 15 October 1892, 609.

51 'Roman Catholic pilgrimage to York', Yorkshire Evening Post, 9 June 1892, 4; Margaret H. Turnham, Catholic faith and practice in England, 1779-1992: the role of revivalism and renewal (Woodbridge: Boydell, 2015), 110; 'Pilgrimage to St Albans', Tablet, 30 June 1900, 1032.

${ }_{52}$ Tablet, 15 October 1892, 609; 'Editorial', Exeter and Plymouth Gazette, 14 October 1897, 6.

53 Western Mail, 9 February 1893, 4.
} 
Dean Purey-Cust (1828-1916) and allowed to kiss St William of York's shrine, perhaps because the Dean was a family friend of $\mathrm{Fr}$ Fletcher's. ${ }^{54}$ Pilgrims were also accommodated at Canterbury by Dean Payne Smith (1818-1895) who granted access to the chapter house. ${ }^{55}$ The general tenor of the early 1890s was one of good relations. In 1893 Kent commented that the 'Protestant authorities ... so far from evincing any objection to these exhibitions of Catholic piety ... have ... courteously granted every facility'. ${ }^{56}$ Where Fr Fletcher found reluctant Protestants, he set out to work on them until pilgrimages were accepted.$^{57} \mathrm{He}$ was not always successful. After 1895, pilgrimages to Canterbury became increasingly fraught. Under Dean Farrar (1895-1903), the pilgrims could only pray silently and surreptitiously. Dean Farrar's former curate, the Rev. W J Sommerville, claimed that the Dean was opposed to what Sommerville called the 'puerile' revival of ceremonies. ${ }^{58}$ His successor, the evangelical Dean Wace (1903-24), also forbade the pilgrims access to the choir, despite his 'reputation for unprejudiced views'. ${ }^{59}$ In contrast, the mood of the civic leadership of Canterbury was apparently more generous: in the early twentieth century the mayor of Canterbury welcomed the pilgrims at the station. ${ }^{60}$

Pilgrimages were also conducted to less famous sites. A pilgrimage to the restored shrine of the Black Madonna at Willesden was initiated. Initially organised by the convert and local Red Cross Ransomer, Prof. Boulger, this pilgrimage soon attracted members of other local Catholic groups, a reflection perhaps of the strongly Irish identity of the parish. ${ }^{61}$ Soon afterwards, about 250 pilgrims made the first pilgrimage to the ruined chapel of Our Lady in Hastings Castle. ${ }^{62}$ Then, in June 1895, the Guild was 'planted' in Holywell. This group went to St Winefride's Well, the oldest site of continuous pilgrimage in Britain; they returned again that November on the date of St Winefride's Feast. ${ }^{63}$ Despite its location in Wales, Holywell had recently been lauded as the 'English Lourdes'. It gave English

\footnotetext{
54 'The York pilgrimage', Tablet, 25 June 1892, 983; Fletcher, Recollections, 82.

55 'Canterbury Pilgrims', St James's Gazette, 10 July 1894, 10; 'Canterbury Pilgrims', Liverpool Daily Post 11 July 1894, 3.

56 Kent, 'People's Ransom', 701.

57 Fletcher, Recollections, 94.

58 Fletcher, Recollections, 72; R. A. Farrar, The life of Frederic William Farrar, New York 1904, 248.

59 'New Dean of Canterbury', Bicester Herald, 10 April 1903, 7.

60 Fletcher, Recollections, 73; Anstruther, 'The Ransomers', 640.

61 Anne Vail, Shrines of Our Lady in England (Leominster: Gracewing, 2004), 221-35 for an account of the shrine; 'Roman Catholic pilgrimage to the shrine of Our Lady of Willesden', Willesden Chronicle, 2 June 1894, 8; 'The Willesden procession', Tablet, 30 September 1905, 540. 62 The pilgrimage grew each year over the following annual pilgrimages. 'Holiday news', Daily Mail, 6 August 1897, 3.

63 'Holywell well record visitors', Flintshire Observer Mining Journal and General Advertiser for the Counties of Flint Denbigh (hereafter FOMJ): 23 May 1895, 5; 'Holywell well record', FOMJ, 13 June 1895, 4.
} 
Catholics a 'domestic site' which linked them to the wider Catholic community, but was also distinctly British. Pilgrimages to the site had continued since the middle ages, ${ }^{64}$ and had been growing in size and number since the start of the 1890s. Nevertheless, the pilgrimages of 1895 were particularly significant for both the Guild and Holywell. The June pilgrimage, which was partly organised by Thomas Cook \& Son, included some 1,400 pilgrims. ${ }^{65}$ It also brought together Fr Fletcher and Fr Beauclerk SJ (1855-1934), the Well's priest.

Together, Fathers Fletcher and Beauclerk were two of the most zealous proponents of the conversion of England and Wales. Fr Beauclerk had been working for this cause at Holywell since the beginning of the decade. In the five years prior to the 1895 pilgrimage, there had been a significant rise in the number of miracles or cures reported there. Fr Fletcher viewed this as evidence that the conversion of the country was near. When Fr Beauclerk preached to pilgrims in 1895, he explained how Fr Fletcher said that Holywell was 'destined to become the centre for the conversion of England. ${ }^{66}$ The popular though controversial preacher Fr Bernard Vaughan SJ (1847-1922) also told the pilgrims that the miracles were a sign that 'God was pleased'. He went to observe that 'as Wales was the last to depart from the Faith, He is making manifest His pleasure here: from Holywell, from Wales, and from Wales through the nations, the wave was spreading like the light from the sun in the heavens. ${ }^{67}$

Arguably, the Guild's greatest impact on pilgrimage was on its restoration of pilgrimage to Our Lady of Walsingham in Norfolk. On 19 and 20 August 1897, Fr Fletcher led the first large-scale post-Reformation pilgrimage to Walsingham. This pilgrimage was in direct response to a plea from Fr George Wrigglesworth (18511900), a White Cross Ransomer and priest in charge of King's Lynn. ${ }^{68}$ Wrigglesworth has been described as the 'pioneer in reestablishing the Roman Catholic Pilgrimage' to Walsingham, ${ }^{69}$ but evidence suggests that the Guild was the key protagonist here. Sean

\footnotetext{
${ }^{64}$ Alexandra Walsham, 'Holywell; Contested Sacred Space in Post-Reformation Wales', in W. Coster and A. Spicer, eds. Sacred Space in Early Modern Europe (Cambridge: Cambridge University Press, 2005), 209-36; Alexandra Walsham, Catholic Reformation in Protestant Britain (Aldershot: Ashgate, 2014), 177-206.

65 'Pilgrimage of the Guild of Ransom', FOMJ, 27 June 1895, 5.

66 'Holywell well record', FOMJ, 3 October 1895, 8. Vaughan's controversial reputation stemmed from a series of debates with the Anglican bishop of Manchester over which Church in England, Catholic or Protestant, had the right to call itself the successor of St Augustine. Accounts of the heated debate filled the pages of The Tablet. For Vaughan's views, see 'Father Bernard Vaughan's Lectures in Reply to the Bishop of Manchester on Roman Claims', Tablet 27 April 1895, 657-61.

67 'Feast of St Winefride', FOMJ, 8 November 1895, 5.

${ }^{68}$ Fletcher, Recollections, 85-6; individual or small-group pilgrimages did take place before this, but they were few. 'East Anglian towns', Norfolk News, 26 September 1896, 3; 'Our Lady of Walsingham', The Monitor, Catholic Organ for Great Britain, 3 June 1898, 5.

${ }^{69}$ Bellenger, 'England's Nazareth', 273.
} 
Gill acknowledged Fr Fletcher as 'one of the prime movers' of Marian revivalism..$^{70}$ Fletcher was able to draw on his extensive experience of organising large-scale pilgrimages, honed over the previous seven years. Wrigglesworth himself recognised the centrality of Fr. Fletcher and the Guild's work, and invited Fr Fletcher to give the evening sermon on the 19 August because he had 'hopes that Ransomers will play an important part in restoring the devotion of Our Lady of Walsingham. ${ }^{71}$ Fr Fletcher actively promoted the pilgrimage in the Catholic press. $\mathrm{He}$ announced it would take place in honour of the new statue of Our Lady, arriving in King's Lynn by train on the morning of the $19^{\text {th }}$, under Ransom escort. He was keen to attract pilgrims from across England; for those who could not attend he encouraged them to 'send a substitute. ${ }^{72} \mathrm{He}$ also addressed the faithful in his column of the London Monitor. He asked for donations of jewels which could be sold to clear the debts of the church in King's Lynn, ${ }^{73}$ and advertised a pilgrimage indulgence in The Monitor for those who contributed. ${ }^{74}$

The pilgrims celebrated Mass before forming a procession, via 'the Walks'. The procession met the statue at the station, and returned via the Mount Chapel, to see the statue installed in its new shrine. ${ }^{75}$ The Guild's 'ownership' of the procession was proclaimed through the Guild's banner, carried at the front, along with the banners of White, Red, and Blue Cross Ransomers. ${ }^{76}$ The Daily Mail reported that the pilgrimage ceremonial 'was carried out by the guild of Our Lady of Ransom', and made no mention of Wrigglesworth, although he was present. ${ }^{77}$ The local press, which often gave detailed coverage of the pilgrimages, also made no mention of Wrigglesworth. Perhaps this was a reflection of the reluctance on the part of the secular press to emphasise the role of Catholic priests. ${ }^{78}$ The next day the pilgrims went to the Slipper Chapel at Walsingham, newly restored by the wealthy benefactress and recent convert, Miss Charlotte Boyd (1837-1906). Fr Fletcher claimed this as one of 'the Ransomed Churches', because it had been freed from non-Catholic ownership. ${ }^{79}$

70 Sean Gill, 'Marian revivalism in modern English Christianity: the example of Walsingham', Studies in Church History 39 (2004), 349-57, at 349 and 351; Jonathan Bush, Papists and Prejudice: Popular Anti-Catholicism and Anglo-Irish Conflict, 1845-1870 (Cambridge: Cambridge Scholars Publishing, 2013), 14.

71 'King's Lynn', The Monitor and Catholic Standard and Ransomer (hereafter MCSR), 21 May $1897,3$.

72 'Advert: King's Lynn', MCSR, 30 July 1897, 1.

73 'King's Lynn', MCSR, 2 July 1897, 3. He acknowledged the receipt of a small parcel of jewels the following July. 'King's Lynn', MCSR, 9 July 1897, 3.

74 MCSR, 6 August 1897, 1.

75 'Guild of Ransom', MCSR, 27 August 1897, 3.

76 Ibid., 3.

77 'A pilgrimage revived', Daily Mail, 23 August 1897, 3.

78 'Roman Catholic pilgrimage', Samford Mercury, 27 August 1897, 6.

79 'Walsingham', MCSR, 27 August 1897, 3. 
Although the Guild was instrumental in the revival of pilgrimage to Walsingham, it also established its own annual pilgrimage to Norfolk. This focused on King's Lynn, where pilgrims circuited the late-medieval Red Mount Chapel. ${ }^{80}$ Their decision may have been intended to recreate that first journey of the statue of Our Lady, after which Fr Fletcher had declared that 'in Lynn shall be revived the glories of Walsingham. ${ }^{81}$ But it was also driven by the decision of Pope Leo XIII, who had transferred the shrine of Our Lady from Walsingham to Lynn because, at the time, there was no suitable Catholic site in Walsingham itself. ${ }^{82}$ One was later developed at the Slipper Chapel and Catholic pilgrimage to Walsingham itself continued before and after that time. Walsingham also, however, became a major centre for Anglo-Catholic pilgrims who had their own shrine in the village. They engaged in 'ritualised medievalism' at Walsingham as a way of establishing their historical identity, although they faced criticism from other Anglicans who were uncomfortable with this form of pre-Reformation Christianity. ${ }^{83}$

Most of these renewed pilgrimages were to pre-Reformation shrines re-dedicated to Our Lady, such as to the shrine of Our Lady of Consolation, West Grinstead, started in $1908 .{ }^{84}$ In part, this Marian emphasis may have been a matter of practicalities: it was more feasible to commission a new statue and restore a Marian shrine than it was to replace lost or destroyed relics. However, Marian pilgrimage was also reinvigorated in the nineteenth century by the definition of the doctrine of the Immaculate Conception of Mary in 1854. Catholics responded with 'a renewed confidence ... and a renewal in the notion of Marian pilgrimage', and, in the specifically English context, they were given the reminder in 1893 that England was 'Mary's Dowry. ${ }^{85}$ However, even at Holywell, where St Winefride's cult was dominant, Fr Beauclerk attributed the increase in pilgrims and associated cures there to the dedication of England to the Virgin in $1893 .{ }^{86}$ Beauclerk was a great enthusiast for Marian devotion, introducing an image of Our Lady of Good Counsel to Holywell in 1894, and erecting of a statue of Our Lady of Victories in St Winefride's Hall, both of which he attributed with miraculous healing power. ${ }^{87}$

\footnotetext{
80 'King's Lynn: Ransom pilgrimage', Tablet, 4 June 1898, 908-9; Bellenger, 'England's Nazareth', 274.

81 'Guild of Ransom', MCSR, 27 August 1897, 3.

82 'Shrine of the Holy House', The Monitor, Catholic Organ for Great Britain, 3 June 1898, 3.

${ }^{83}$ Simon Coleman and John Elsner, 'Pilgrimage to Walsingham and the Re-Invention of the Middle Ages', in Pilgrimage Explored ed. J. Stopford (York: York Medieval Press, 1999), 189-214.

84 'Pilgrimage to West Grinstead', Tablet, 18 July 1908, 101.

${ }^{85}$ Paul Severn, 'A history of Christian pilgrimage', International Journal for the Study of the Christian Church 19.4 (2019): 333; Alpha Omega XXIII n3 (2010): 429. For Marian Revivalism, see Cadoc D. A. Leighton, 'Mary and the Catholic Church in England, 1854-1893', Journal of Religious History 39 (2015): 68-85.

86 'Holywell well record', FOMJ, 3 October 1895, 8.

${ }^{87}$ T. W. Pritchard, St Winefride, her holy well, and the Jesuit Mission, c. 650-1930 (Wrexham: Bridge Books, 2009), 318-19.
} 


\section{Pilgrimage and post-Reformation martyrs}

The other pilgrimages organised by the Guild of Our Lady of Ransom either focused on sites purely associated with post-Reformation martyrs, or developed pre-Reformation pilgrimage destinations to incorporate the veneration of post-Reformation martyrs. Connecting to the English past was critical if the Guild were to achieve its central aim of conversion. In 1884, St George Jackson Mivart, a convert, claimed that the conversion longed for since the Restoration of 1850 had not happened because Catholicism 'rejected English customs and national characteristics' ${ }^{88}$ The Guild's association with English Martyrs, in its own patronage, and in the choice of pilgrimage sites, arguably helped to bridge the gap between English and Catholic identities, and went some way to addressing Mivart's concerns. It therefore served a dual purpose of emphasising English identity and, at some locations, providing pilgrimage destinations outside the control of the Established Church.

Guild development of pilgrimage to these sites coincided with the recognition of the English martyrs. Pope Leo XIII beatified 54 in 1886, including John Fisher (d. 1535) and Thomas More (d. 1535), and another nine in 1895 (the Nine Martyrs of England and Wales). ${ }^{89}$ These beatifications led to an increased interest in, and veneration of, these figures, and resulted in the publication of several Lives. Stories of these martyrs 'became part of the popular culture of English Catholicism. ${ }^{90}$ There was also a general interest in other postReformation martyrs, including Ambrose Barlow (d. 1641), the focus of a pilgrimage in $1893 .{ }^{91}$ Honouring these martyrs aligned well with the Guild's mission of conversion; hymns composed at this time called on the martyrs to 'win our country to Christ again'.$^{92}$ More specifically, Fr Fletcher had a particular devotion to them, holding the Guild's first annual service at the church of the English Martyrs at Tower Hill. He wrote in The Tablet that those who attended would 'practically be making a pilgrimage' to the site where so many martyrs died. ${ }^{93}$

The first Ransom pilgrimage honouring the Blessed English Martyrs was held in May 1890. Nearly one thousand pilgrims converged on the Tower of London, far more than had been anticipated.

${ }^{88}$ Holmes, More Roman than Rome, 249; St G. J. Mivart, 'The Conversion of England', Dublin Review XII (1884), 65-86.

89 Underwood, 'English Catholic martyrs', 144-50.

90 Judith Champ, The English pilgrimage to Rome: a dwelling for the soul (Leominster: Gracewing, 2000), 150.

91 'A Manchester martyr', Tablet, 2 September 1893, 382; Underwood, 'English Catholic martyrs', 151.

92 Ibid., 153.

93 Letter from Father Fletcher, Tablet, 27 April 1889, 24. 
The Tower's warders, who had been accommodating to the pilgrims, took the decision to shut the gate due to the size of the crowd. Those who managed to gain admittance prayed at Blessed John Fisher's grave, and the execution site of Blessed Thomas More. ${ }^{94}$ The Catholic press repeatedly mentioned More and Fisher in their reports, but according to the London papers, the pilgrimage had a third focus Margaret Pole, Countess of Salisbury (d. 1541), beatified in $1886 .{ }^{95}$ More was also the focus of the Ransom pilgrimage to his former home and garden in Chelsea, and to Chelsea Old Church, where he had commissioned the southern chapel. ${ }^{96}$ The Guild's reverence of More was such that he was included in all special pilgrimage prayers in the Ransom Prayer Book. ${ }^{97}$ In August 1901, they conducted a new pilgrimage in honour of the English Martyrs and St Thomas Becket, although the Martyrs were the primary focus. Their destination was the Benedictine monastery of Erdington, home of the convert Fr Bede Camm (1864-1942), author of Lives of the English Martyrs (1904) and Forgotten English Shrines (1910) ${ }^{98}$ Camm amassed a considerable collection of martyr relics, and agreed with Fr Fletcher to establish an annual pilgrimage to honour them..$^{99}$ The highlight of the pilgrimage was the procession of the relics through the abbey grounds. ${ }^{100}$

The York pilgrimage was expanded over time to include other sites associated with the English Martyrs. Veneration of Margaret Clitheroe's hand at Bar Convent was a feature from the start. This was probably as a result of her local prominence, as she was not beatified until 1929. Over time, the pilgrims came to visit the Guildhall where the York Martyrs were sentenced, and prayed at the temporary church of the English Martyrs. After his beatification in May 1895, the execution and burial place of the Blessed Thomas Percy (d. 1572), earl of Northumberland was also a site for prayer. ${ }^{101}$ A similar pattern of expanding existing pilgrimages to encompass post-Reformation

\footnotetext{
94 'News from the dioceses', Tablet, 10 May 1890, 750.

95 'A pilgrimage to the Tower', Pall Mall Gazette, 6 May 1890, 5; St James' Gazette, 6 May 1890, 9; John Bull, 10 May 1890, 14.

${ }^{96}$ Fletcher, Recollections, 91-3; 'Chelsea: pilgrimage to Blessed Thomas More's shrine', Tablet, 12 July $1913,76$.

97 'Oddments in an odd order', Moreana, 19 (1982): 46.

${ }^{98}$ Dominic Aiden Bellenger, 'Dom Bede Camm (1864-1942), Monastic Martyrologist', in Diana Wood, ed. Martyrs and martyrologies: papers read at the 1992 Summer Meeting and the 1993 Winter Meeting of the Ecclesiastical History Society (Oxford: Blackwell, 1993), 371-81.

${ }_{99}$ Fletcher, Recollections, 102; Bede Camm, Forgotten shrines: an account of some old Catholic halls and families in England and of relics and memorials of the English Martyrs (London: Macdonald and Evans, 1910), 244-5.

100 'Pilgrimage', Tablet, 2 August 1902, 193. The Erdington pilgrimage seems to have ended on the eve of the First World War after which it was 'replaced' by the Ransomers' pilgrimage to St Chad's Cathedral in Birmingham. Fletcher, Recollections, 103.

101 'The York pilgrimage', Tablet, 25 June 1892, 983; 'The York pilgrimage', Tablet, 16 June 1894, 940; 'Roman Catholic pilgrimage to York', Sheffield Daily Telegraph, 11 June 1895, 7; 'Pilgrimage to York', Tablet, 20 June 1896, 994; Underwood, 'English Catholic Martyrs', 151.
} 
martyrs was also seen at Canterbury. The site of Blessed John Stone's (d. 1539) martyrdom, and the church of St Dunstan, which possessed Thomas More's head, became part of the pilgrimage itinerary. ${ }^{102}$ Devotion to the English martyrs was also demonstrated when the Ransomers joined the 1895 pilgrimage to Glastonbury Tor, in honour of Abbot John Whiting and his monks, Roger James and John Thorne, martyred there in $1539 .{ }^{103}$

In the early twentieth century, the Guild developed a pilgrimage to a new site associated only with post-Reformation martyrdom. The first Ransom pilgrimage to Padley in Derbyshire took place in 1904, when pilgrims visited the ruined chapel at Padley Manor, then used as a cowshed. ${ }^{104}$ Padley was the site of the arrest of Nicholas Garlick and Robert Ludlum, the so-called 'Padley Martyrs', in July 1588. They had been declared Venerable in 1888 by Pope Leo XIII. ${ }^{105}$ Preaching to the pilgrims in 1907, Canon Dolan said that the 'sight of its walls might well draw tears' because of what had happened there. ${ }^{106}$

There are some interesting omissions from Ransom pilgrimages. The Guild was established on the feast day of St Willibrord (d. 739), patron saint of the Netherlands and Luxembourg, yet there was no pilgrimage in his honour, perhaps due to the lack of a shrine in England. The day of the establishment of the Guild was also the anniversary of the death of Blessed Cuthbert Mayne, (d. 1577). Mayne's skull was in England, at the Carmelite convent at Lanherne, where it was first presented for public veneration in November 1899. A pilgrimage in Mayne's honour to his place of execution in Launceston (Cornwall) was inaugurated in 1921, at was not the responsibility of the Guild. Similarly, the Guild took as its prayer the final words of the Venerable Henry Heath, executed at Tyburn, and the Tyburn pilgrimages would have included him as one of the dead, but the Guild did not single him out. The rationale behind Guild choices was thus influenced by a range of factors, from papal promotion to personal preferences.

\section{Situating the Guild in Nineteenth Century Religiosity and Society}

The underlying factor in the mix of destinations chosen by the Guild - a combination of pre-and post-Reformation saints, as well as Marian shrines - reflected wider efforts to position the late nineteenth-century Catholic Church so as to emphasise continuity with England's medieval past, and the continuity of Catholic faith despite the Reformation. This

\footnotetext{
102 'Pilgrimage to Canterbury', Tablet, 29 July 1893, 185; Kent, 'People's Ransom', 701.

103 Bristol Times and Mirror, 12 August 1895, 5.

104 Tablet, 13 August 1904, 245. The barn was eventually bought by the diocese in 1930s and restored so that Mass could take place inside the building where the twelfth century altar was restored. 'Padley Chapel pilgrimage', The Manchester Guardian, 19 July 1935, 9.

105 They would not be beatified until 1987.

106 'The Padley martyrs', Tablet, 20 July 1907, 107.
} 
can most readily be seen in the construction of Westminster Cathedral by Cardinal Archbishop Vaughan, a Ransomer. Vaughan sought to merge Roman Catholic and English Catholic identities and 'locate them firmly within Britain's historical landscape' in the cathedral, by trying to secure relics of the most important pre-Reformation English saints like St Thomas Becket and St William of York. ${ }^{107}$ In some respects, Fr Fletcher's choice of pilgrimage destination foreshadowed Vaughan's activities. Marian pilgrimage was an important expression of England's position as Mary's Dowry, but it also reflected wider continental trends driven by the rise of Lourdes, and the desire of some English Catholics to appear 'more Roman than Rome'. ${ }^{108}$

The interest in Marian sites, and sites associated with the English Martyrs, are understandable given the promotion of Mariology, and the English martyrs, by Pope Leo XIII. However, some were chosen over others for wholly prosaic reasons. The Hastings pilgrimage 'was founded by Mr Lister Drummond, its true lover'. ${ }^{109}$ His enthusiasm was driven by a photograph of the ruined chapel which highlighted a statue of Our Lady in a shaft of light, an event which 'immediately suggested to Mr Drummond the idea of annually escorting a statue of the Virgin to the shrine'. Drummond also seemed to have a particular affection for the town, where he had many friends. ${ }^{110}$ Drummond's devotions also influenced the pilgrimages to Thomas More's house in Chelsea: he was a lawyer at Lincoln's Inn, which had connections to More's father and grandfather, and he was sufficiently devoted to More to push for the erection of his statue on the Inn's outer wall. ${ }^{111}$ Pilgrimage to Padley was established, not by the Guild, but by Canon Dolan of St Marie's, Sheffield, and only put under the control of the Guild later on. ${ }^{112}$ Before moving to Sheffield, he had been the priest of the English Martyrs in York, where he had assisted in the organisation of the annual Ransom pilgrimage. ${ }^{113}$ His involvement in these pilgrimages would have given him the model and the experience to establish the Padley pilgrimage.

Several sites were chosen because of the ease of access afforded to them by train travel. Fr Fletcher was a railway enthusiast and spent years travelling 'the nomad life' by train. ${ }^{114}$ Using railways for

\footnotetext{
107 John Jenkins and Alana Harris, 'More English than the English, More Roman than Rome? Historical signifiers and cultural memory at Westminster Cathedral', Religion 49 (2015), 48-73, at 52-56.

108 Jenkins and Harris, 'More English than the English', 50.

109 Fletcher, Recollections, 95.

110 Dorothy Gladys Spicer, Yearbook of English festivals (New York: Wilson, 1954), 107; 'Hastings, King's Lynn', MCSR, 16 July 1897, 3.

111 L. Goulder, 'Thomas More's London', The Catholic Lawyer 13 (1967): 10.

112 Fletcher, Recollections, 93; 'Two English martyrs', Tablet, 21 July 1934, 74.

113 'The York pilgrimage', MCSR, 14 May 1897, 3; 'York pilgrimage', MCSR, 4 June 1897, 3.

114 Fletcher, Recollections, 57.
} 
pilgrimages had been popular in England since the 1873 pilgrimage to Paray-le-Monial. This coincided with the development of mass commercial tourism, led by the Methodist Thomas Cook, who organised pilgrimages overseas and within Britain. ${ }^{115}$ The Guild hoped to attract large numbers on what were unambiguously religious pilgrimages, but to make them convenient enough that they could be carried out within a day. The Guild thus sought to capitalise on the late Victorian love of day-tripping, blending pilgrimage with the popular vogue for organized leisure. Here the Guild effectively acted as a tour operator, actions which heralded the modern development of pilgrimage into religious tourism. ${ }^{116}$ Pilgrimages via train were highly organised, using special trains where possible, and incorporating religious activities into the railway journey. ${ }^{117}$ Pilgrims to Holywell had a 'manual prepared for the occasion', which covered pre- and post-pilgrimage activities, and gave instructions for the journey by special train from Lime Street Station, Liverpool. ${ }^{118}$ More pilgrims also joined the trains at various stops along the way. ${ }^{119}$ The pilgrimage site at Padley was more remote, but it was nevertheless accessible by train from nearby Grindleford station. ${ }^{\prime 20}$ Interestingly, though the pilgrims venerated Garlick at Padley, the burial of his head at nearby Tideswell did not attract them, perhaps because its nearest train station was nearly an hour's walk from the church.

Whether to old or new sites, the pilgrimages took on the same form of prayer, procession, and veneration, confirming Mary Heimann's assertion that Victorian and Edwardian pilgrimages 'self-consciously recreated the habits of medieval worshippers'. ${ }^{21}$ The look of the Guild was thought out by Fr. Fletcher, with the colours of the various Ransom groups being based on those used by the Trinitarians. The Guild's various organisers were keen to have their banners carried, sending them to places ahead of time. ${ }^{122}$ Their use in processions proclaimed the Guild's identity: a banner with the Five Wounds of Christ, modelled on that carried during the 1536 Pilgrimage of Grace,

115 T. Larsen, 'Thomas Cook, Holy Land pilgrims, and the dawn of the modern tourist', Studies in Church History 36 (2000): 329-42; Piers Brendon, Thomas Cook: 150 years of popular tourism (London: Secker and Warburg), 1991.

116 Ian Reader, Pilgrimage: a Very Short Introduction (Oxford: Oxford University Press, 2015), 13-15; Ian Reader, Pilgrimage in the Martketplace (New York: Routledge, 2014), 188; G. Rinschede, 'Forms of Religious Tourism', Annals of Tourism Research 19 (1992): 51-67; for the debate on the differences between pilgrimage and religious tourism, see Antoni Jackowski, 'Religious Tourism - Problems with Terminology', Peregrinus Cracoviensis 10 (2000), 63-74 and the articles in Daniel H. Olsen and Dallen J Timothy, eds. Tourism, Religion and Spiritual Journeys (London: Routledge, 2006).

117 'Pilgrimage to Canterbury', Tablet, 29 July 1893, 185.

118 'Holywell well record', FOMJ, 27 June 1895, 5.

119 'The pilgrimage to Canterbury', Tablet, 11 July 1896, 66.

120 'Roman Catholic pilgrimage to Padley', The Manchester Guardian, 17 July 1914, 10.

121 Heimann, 'Christian piety in Britain', 47.

122 York Herald, 9 June 1893, 6. 
accompanied the York pilgrimage in 1892. The local press recognised and reported on these local associations. ${ }^{123}$ The King's Lynn pilgrimage of 1898 featured a candlelit procession where hymns were sung to accompany the statue of Our Lady of Ransom. Seven banners were carried in the procession: the first was the banner of St Patrick's, Soho Square, a church recently built for the area's Irish community. Banner-carrying was accompanied by groups holding candles, young girls dressed in white, churchmen in their regalia, and a choir, or several choirs on the large pilgrimages. All of these elements added to the religious atmosphere of the event and addressed the sensory expectations and requirements of pilgrimages which had been important since the middle ages: harmonious singing, light and colour suggesting purity and sanctity, and images of holiness which the pilgrims could contemplate. ${ }^{124}$ The final destinations were often statues, shrines, or relics which were venerated, allowing pilgrims to engage with sanctity via sight and sound. Elsewhere, they were confronted with ruins or open spaces which were given spiritual significance by the preachers in attendance, creating mental images of the events which had occurred there. There are, however, no references to pilgrims being allowed to touch most holy objects at sites, and their actions were largely confined to quiet prayer. The exception, and thus the most sensory experience, was at St Winefride's in Holywell, where the pilgrims bathed in the cold well, or drank in hope of a cure. ${ }^{125}$

In addition to thinking carefully about the logistics of mass pilgrimage, Fr Fletcher was also keen to obtain benefits for pilgrims who were doing the 'work' of praying for the conversion of England. He secured indulgences from the bishop of Middlesbrough for pilgrims to York, and from the archbishop of Westminster for those to St Albans. ${ }^{126}$ Drummond also arranged for discounted train tickets to make it affordable, much as a travel agent would, and advertised these in the Catholic Press. ${ }^{127}$ One Guild advert for the first St Alban's pilgrimage advised readers that they could gain half-price admission to the shrine there on the production of their Ransom medal. ${ }^{128}$ In addition to adverts and letters printed in a variety of newspapers, the Guild promoted pilgrimage through its local networks. In areas where there were

123 'Pilgrimage to York', Yorkshire Gazette 11 June 1892, 5.

124 Dee Dyas, The Dynamics of Pilgrimage: Christianity, Holy Places and Sensory Experience (London: Routledge, 2020), esp. ch 7, and Dee Dyas, 'The Role of Sensory Engagement with Place, Past, and Present', in Dee Dyas and John Jenkins, eds. Pilgrimage and England's Cathedrals, Past, Present and Future (Cham: Palgrave Macmillan, 2020), 193-213.

125 'Holywell', The Monitor and Catholic Standard and Ransomer 3 September 1897, 3.

126 'Pilgrimage to York', Tablet, 20 June 1896, 994; Tablet, 4 June 1898, 908.

127 'Pilgrimage to Canterbury', Tablet, 21 June 1890, 983; 'Guild of Our Lady of Ransom', Tablet, 4 July 1891, 16.

128 Advertisement, The Monitor and New Era, 15 June 1900, 1. 
Red Cross Ransomers, the district Ransomer would often assist with the local logistics of the pilgrimage. ${ }^{129}$

Guild pilgrimages were not without controversy, and were sometimes attacked in the press. In May 1893, readers of The Sunday at Home, one of the most successful pious weeklies published by the evangelical Religious Tract Society, were warned about the intention of the Guild to restore 'Popery and the Mass!' and the 'vagaries' of their activities, including pilgrimages. While the article's author conceded Catholics had the right to worship, in undertaking pilgrimages, they argued, 'they were guilty of a distinct violation of the law of the land. The custodians of Canterbury Cathedral in particular, it was argued, had failed to 'abjure the doctrines of Romanism' by letting the pilgrims in. ${ }^{130}$ In the same year, George Cullwick, a Protestant polemicist, wrote to the Manchester Courier to complain about a recent pilgrimage by the Guild in honour of Ambrose Barlow (d. 1641) to Barlow Hall. Cullwick argued a pilgrim was 'a traitor, [who might] express sympathy with treason', and that if these pilgrimage 'were to be used for disloyal purposes', they should be stopped. ${ }^{131}$

Other opposition was staged at or near active pilgrimages. In keeping with more widespread anti-Catholicism, this tended to be oral rather than printed. ${ }^{132}$ At Hastings, there was hostility from a few anonymous Protestants in 1899 when they distributed a leaflet by the National Protestant Federation. The leaflet cited an obsolete proclamation, of 46 years previously, which banned Catholic processions. ${ }^{133}$ There were also rumours that the pilgrimage procession would be attacked, and some rival hymn-singing took place. ${ }^{134}$ In 1904, there were rumours of someone in the crowd shouting 'Idolatry!' as the procession passed and several 'bitter' letters appeared in the local press. ${ }^{135}$ In 1900, a meeting was held by unnamed individuals in the De Grey Rooms in York, 'in defence of the Protestant Faith', as the Ransom pilgrimage was underway. ${ }^{136}$ The occurrence of these protests in more urbanised areas also reflected wider trends, as most popular anti-Catholicism was urban in nature, and antiCatholicism as a whole tended to manifest in local forms, rather than

\footnotetext{
129 The American Catholic Quarterly Review 16 (1891): 373.

130 'Things new and old', The Sunday at Home: a family magazine for Sabbath reading 40 (1893), 446; Rosemary Scott, 'The Sunday periodical: Sunday at Home', Victorian Periodicals Review 25 (1992): 159-60.

131 'Roman Catholic Pilgrimage Near Manchester [Letter]', Manchester Courier and Lancashire General Advertiser, 16 September 1893, 9.

132 John Wolffe, 'A comparative historical categorisation of anti-Catholicism', Journal of Religious History 39 (2015): 182-202, at 197.

133 'Ransom procession at Hastings', Tablet, 19 August 1899, 312.

134 Ibid., 313.

135 'Tolerant Hastings', Hastings and St Leonard's Observer, 13 August 1904; 'Tolerant Hastings', Hastings and St Leonard's Observer, 27 August 1904, 3.

136 'The defence of Protestantism', Daily Gazette for Middlesbrough, 11 June 1900, 5.
} 
as a national movement. ${ }^{137}$ Most pilgrimages took place without comment, let alone protest. This suggests that Hugh MacLeod's argument, that nineteenth-century Protestantism was pervasively anti-Catholic, was not also borne out across the country. ${ }^{138}$ Indeed, a reporter for the Yorkshire Gazette attributed the peaceful execution of the 1893 York pilgrimage to 'the remarkable toleration of the age'. ${ }^{139}$ Such observations are reflective of the idea that popular anti-Catholicism was on the wane, and that though critics still attacked the papacy, devotion, even if practiced here in a more public arena, was considered a private matter. ${ }^{140}$ Even so, Fr Fletcher was fully cognizant of the criticisms levelled at the Guild, so much so that he set up a 'Body Guard' to work at public events, and a 'Watchtower Department' to 'answer misrepresentation in the papers'. Most of the criticism appeared in relation to processions and preaching, and in reports of alleged attacks staged by Ransomers on Protestant lecturers. ${ }^{141}$ In reality, a large number of Protestant clergy, the secular press, and the watching public were generally accommodating of the pilgrimages. ${ }^{142}$

\section{Conclusions}

Mass pilgrimage in Britain during the final decade of the nineteenth century was driven by the Guild of Our Lady of Ransom. Under Fr Fletcher's leadership, the Guild was responsible for the restoration of pilgrimage to one of the most important pilgrimage sites in England, Walsingham, a fact which has been overshadowed by the later development of the medieval site under its Anglo-Catholic priest, Alfred Hope Patten (1885-1958). The Guild's success in attracting such large numbers, and repeating pilgrimages year on year, lay in the organizational skills of its leaders, and their utilisation of modern advertising and travel methods. They drew to some extent on the methods of previous railway pilgrimages, but their success was also part of a wider expansion of train travel and package holidays. ${ }^{143}$ The Guild's widely acknowledged successes resulted in its being actively courted by businesses wanting to advertise their own pilgrimage excursions. 'I was

137 Wolffe, 'A comparative historical categorisation': 198; 'Pilgrimage to York', Yorkshire Gazette 11 June 1892, 5.

138 Hugh MacLeod, Secularisation in Western Europe, 1848-1914 (Basingstoke: Palgrave, 2000), esp ch. 7.

139 'Pilgrimage to York', Yorkshire Gazette 11 June 1892, 5.

140 Yvonne Maria Werner and Jonas Harvard, 'European anti-Catholicism in comparative and transnational perspective', in Werner and Harvard, eds. European Anti-Catholicism in a Comparative and Transnational Perspective, 13-24, at 14-16; Margulis Anne Drury, 'Anti-Catholicism in Germany, Britain, and the United States', Church History 70 (2001): 98-131.

141 London Monitor, 25 November 1898, 3.

142 The American Catholic Quarterly Review 16 (1891): 375; Fletcher, Recollections, 65, 107-

8; Turnham, Catholic Faith and Practice, 111; The Churchman 61 (1890): 521.

143 Turnham, Catholic Faith, 109. 
approached by the organising secretary of a new Travel Company (an imitation of Thomas Cook)', Fr Fletcher recalled, 'with a view to making a pilgrimage to the old Abbey of St Brendan, one of the discoverers of America. Being a young company needing advertisement, they gave us a special to Holyhead. ${ }^{144}$ Undoubtedly, Fr Fletcher's significant publication output promoted the Guild's activities and helped to attract pilgrims, but regional promotion, undocumented for the most part, took place through local Ransom networks and succeeded in swelling the ranks of the Guild's processions. As a result, pilgrims travelled some distance to engage with these events. They were keen to stamp the corporate identity of their Guild on processions. They did so through the wearing of badges, the use of banners in procession, ${ }^{145}$ and the commissioning of special carriages reserved for pilgrims on their railway journey. The ability of Fr Fletcher to organise mass pilgrimages was recognised by Fr Wrigglesworth at King's Lynn, and Canon Dolan of Sheffield; both men invited him to take charge of their respective pilgrimage activities. Such personal connections drove many of their activities, as did personal interest in sites like Hastings and Chelsea, and their ability to gain access to sites controlled by the Established Church.

The large annual pilgrimages organised and run by the Guild had a heavy emphasis on post-Reformation martyrs or Marian shrines: only the Westminster pilgrimage did not. Post-Reformation martyrs and the sites associated with them were chosen because so many medieval sites had been destroyed in the sixteenth century, and because many medieval sites were under the control of the Established Church. ${ }^{146}$ However, by the early 1890s, Protestant clergy were accommodating and allowed Catholic pilgrims into their buildings. Even when they did not, as at Canterbury after 1895, discreet pilgrimages were still conducted. This almost perfect storm of the $1890 \mathrm{~s}$ - easier mass transport, greater toleration from the Established Church, the beatification of numerous English Martyrs, the rise in Mariology - coincided with the enthusiasm of Fr Fletcher and Lester Drummond and the members of their Guild to create the revival, restoration, and creation, of some of the most famous and enduring pilgrimages in modern Britain.

\footnotetext{
144 Fletcher, Recollections, 190.

145 'Remarkable scenes', Sheffield Daily Telegraph, 26 May 1896, 3; 'Impressive scenes at Holywell', Daily Gazette for Middlesbrough, 26 May 1896, 4.

146 Alexandra Walsham, 'Mobile martyrs and forgotten shrines: the translation and domestication of relics in post-reformation England', in Antón Pazos, ed. Relics, Shrines and Pilgrimages: Sanctity in Europe from Late Antiquity (Abingdon: Routledge, 2020), 181-95.
} 